\title{
Trophodynamics of the deep-water suprabenthic mysid Boreomysis arctica in the Catalan Sea (western Mediterranean)
}

\author{
J. E. Cartes*, F. Maynou \\ Institut de Ciències del Mar (CSIC), Plaça del Mar s/n, 08039 Barcelona, Spain
}

\begin{abstract}
Gut-evacuation rate $(R)$, and daily ration $(D R)$ were studied in the bathyal mysid Boreomysis arctica, a dominant species from the suprabenthic assemblage of the Catalan Sea, during a ca 72 h day-night sampling cycle (Cruise BT1 of March 1994) at depths from 638 to $1256 \mathrm{~m}$. Although the density of $B$. arctica was higher during daytime in the water column between 0.1 and $1.5 \mathrm{~m}$ above the sea floor, no significant changes in day-night density were recorded. Feeding peaks were detected during 2 consecutive days in the morning (between 09:59 and 11:58 h), while during the evening and night (between 16:09 and 01:28 h), feeding intensity decreased. The $R$ obtained from field data $\left(R_{\max }\right)$ was $0.114 \mathrm{~h}^{-1}$, whereas the $R$ obtained from experimentally starved specimens collected during Cruise BBC1 of March 1998 varied between $0.141 \mathrm{~h}^{-1}\left(3\right.$ specimens) and $0.345 \mathrm{~h}^{-1}$ (1 specimen). The DR calculated with Elliott and Persson model ranged from 13.51 to $15.05 \%$ dry wt for $R$ of $0.114 \mathrm{~h}^{-1}$ and $R 0.141 \mathrm{~h}^{-1}$, respectively. The $D R$ obtained for $B$. arctica was higher than the range of $D R$ reported for megafaunal deep-sea decapod crustaceans in the same area (between 0.260 and $4.820 \%$ dry wt), but fell within the $D R$ range reported for pelagic zooplankton (euphausiids, hyperiids, calanoids). Adopting $0.6 \mathrm{~g} \mathrm{C} \mathrm{m}^{-2}$ as the mean annual organic carbon consumption of the sediment community from the neigbouring Lacaze-Duthier canyon (north Catalan Sea), B. arctica would consume ca $3.4 \%$ of organic carbon annually. Therefore, the trophic impact of this bathyal species is low compared to its numerical dominance in bathyal assemblages, and is often lower than that reported for mesopelagic species.
\end{abstract}

KEY WORDS: Daily ration · Food consumption $\cdot$ Suprabenthos $\cdot$ Gut-evacuation rates $\cdot$ Deep-sea communities

\section{INTRODUCTION}

The study of the grazing or predatory impact of consumer species is of particular interest in trophic ecology and in the study of the carbon cycle, for determining the amount of food (energy) transferred through trophic webs. Field estimation of the daily ration $(D R)$ consumed by predator species constitutes a good approach to establishing the trophic impact of numerically abundant species, thus extending the knowledge on trophic structure and ecosystem functioning beyond dietary studies.

*E-mail: jcartes@icm.csic.es
Recently, $D R$ studies have been widely used in marine ecology, being mainly focused on fishes, and particularly on those fish species of commercial interest (Durbin et al. 1983, Macpherson 1985, Bulman \& Koslow 1992, among others). However, similar studies estimating the predatory impact by zooplankton (particularly copepods and euphausiids) have also been published (Ponomareva \& Kuznetsova 1995, Froneman et al. 1996, Perissinotto et al. 1997, and references therein). The latter studies dealt with species that, due to their abundance and low trophic level, can significantly contribute to the carbon flux in marine systems and provide a link between primary production and fisheries production. Most published works are mainly 
restricted to the euphotic zone or areas of global interest, such as the Antarctic Ocean: e.g. studies made on Euphausia superba, a key species supporting Antarctic trophic webs (Pakhomov et al. 1997a), some other mesoplanktonic species, mainly copepods (see Atkinson et al. 1992, Pakhomov et al. 1997b, Ward et al. 1995) from that same area, or euphausiids from upwelling systems (Ponomareva \& Kutznezova 1995 and references therein). The methods employed often differ for megafauna and meso/macroplankton: Thus, while gutevacuation rates have been mainly used to estimate rations in large megafauna (fishes, decapod crustaceans), methods such as ingestion rates, gut-pigment contents and faecal pellet evacuation rates have been more widely employed for mesozooplankton (see also Peterson et al. 1990 for a comparison of methods employed for mesoplankton).

The largest ecosystem on the planet, the deep sea, has only recently been the subject of such studies. Trophic aspects are recognised as the main limiting factor in deep-water ecosystem dynamics. Trophic aspects are also often invoked as the main factor explaining the high diversification of deep-sea fauna at evolutionary time scales, as discussed by Gage \& Tyler (1991). Nevertheless, information on food consumption by deep-sea fauna is still very scarce, and restricted to some fishes and decapod crustacean species (Gorelova 1986, Bulman \& Koslow 1992, Maynou \& Cartes 1997, 1998; Cartes \& Maynou 1998). For lower trophic levels, information is almost non-existent, although some in situ data on grazing impact exist for mixed (meso-) zooplankton in the deep-sea benthic boundary layer (BBL; Wishner \& MeiseMunns 1984, Wishner \& Gowing 1992). The BBL is a level of high biological activity, and is defined as the sediment-water interface with an upper limit at around 50 to $100 \mathrm{~m}$ above the sea floor (cf. Jumars \& Gallagher 1982, Wishner \& Gowing 1992).

The biomass of fishes and large invertebrates inhabiting the deep BBL is mainly sustained by the production of the detritus-feeding macrofauna. It has been suggested, and sometimes documented, that this faunal compartment acts as a direct or indirect link coupled to surface primary production. Dietary studies on this fauna are scarce, but studies trying to estimate the amount of food consumed are almost non-existent. The mysid Boreomysis arctica is a good target species for this type of study, because of its dominance in suprabenthic (= hyperbenthic) communities of the deep Mediterranean. B. arctica is distributed between 389 and $1859 \mathrm{~m}$ in the northwestern Mediterranean, reaching maximum abundance at midslope levels (ca 500 to $600 \mathrm{~m}$; Cartes \& Sorbe 1998). This species forms an important part of the total biomass in bathyal suprabenthic communities. Its diet is based on a variety of food sources of planktonic origin. It is the only suprabenthic species in which a high consumption of phytodetritus (25 to $60 \%$ of stomach volume) has been documented (Cartes \& Sorbe 1998). $B$. arctica is also a key prey in the diet of deep-sea fishes such as Lepidion lepidion and Bathypterois mediterraneus (Carrasson et al. 1998, unpubl. data), and of some large decapods (i.e. Polychelidae, Aristeus antennatus) which are distributed across a wide depth range, reaching depths below $1000 \mathrm{~m}$ (Cartes 1998).

In the present study, we estimate the gut-evacuation rate, the daily ration and the grazing impact of Boreomysis arctica in mid-bathyal communities of the BBL in the northwestern Mediterranean.

\section{MATERIALS AND METHODS}

Daily changes in stomach fullness. During Oceanographic Cruise BT1 of the RV 'García del Cid' (March 1994) a $\sim 72 \mathrm{~h}$ suprabenthos sampling cycle was performed. Sampling was carried out over the Catalan Sea

Table 1. Sampling locations and sampling details of hauks on Cruise BT1 (March 1994). Vol.: volume filtered by sled nets in a tow; D/N: day or night tow; $\mathrm{n}$ : number of mysids measured

\begin{tabular}{|c|c|c|c|c|c|c|}
\hline & Location & $\begin{array}{l}\text { Depth } \\
\text { (m) }\end{array}$ & $\begin{array}{l}\text { Start time } \\
\text { (GMT) }\end{array}$ & $\begin{array}{l}\text { Vol. } \\
\left(\mathrm{m}^{3}\right)\end{array}$ & $\mathrm{D} / \mathrm{N}$ & $\mathrm{n}$ \\
\hline \multicolumn{7}{|l|}{$21 \mathrm{March}$} \\
\hline BT1/1 & $41^{\circ} 10.5^{\prime} \mathrm{N}, 2^{\circ} 24.4^{\prime} \mathrm{E}$ & $656-660$ & 09:59 & 616 & $\mathrm{D}$ & 55 \\
\hline $\mathrm{BT} 1 / 2$ & $41^{\circ} 11.5^{\prime} \mathrm{N}, 2^{\circ} 26.5^{\prime} \mathrm{E}$ & $655-646$ & $11: 23$ & 729 & $\mathrm{D}$ & 116 \\
\hline $\mathrm{BT} 1 / 4$ & $41^{\circ} 00.4^{\prime} \mathrm{N}, 2^{\circ} 17.2^{\prime} \mathrm{E}$ & $1204-1207$ & $16: 09$ & 1084 & $\mathrm{D}$ & 59 \\
\hline $\mathrm{BT} 1 / 5$ & $40^{\circ} 59.7^{\prime} \mathrm{N}, 2^{\circ} 16.2^{\prime} \mathrm{E}$ & $1203-1193$ & $20: 51$ & 892 & $\mathrm{~N}$ & 55 \\
\hline BT1/6 & $41^{\circ} 01.4^{\prime} \mathrm{N}, 2^{\circ} 17.2^{\prime} \mathrm{E}$ & $1192-1228$ & $22: 53$ & 841 & $\mathrm{~N}$ & 66 \\
\hline \multicolumn{7}{|l|}{22 March } \\
\hline BT1/7 & $41^{\circ} 09.4^{\prime} \mathrm{N}, 2^{\circ} 20.9^{\prime} \mathrm{E}$ & $656-638$ & 01:08 & 388 & $\mathrm{~N}$ & 12 \\
\hline BT1/8 & $41^{\circ} 09.5^{\prime} \mathrm{N}, 2^{\circ} 21.9^{\prime} \mathrm{E}$ & $667-671$ & $11: 58$ & 550 & $\mathrm{D}$ & 47 \\
\hline BT1/9 & $41^{\circ} 10.7^{\prime} \mathrm{N}, 2^{\circ} 24.2^{\prime} \mathrm{E}$ & $644-650$ & $13: 29$ & 562 & $\mathrm{D}$ & 95 \\
\hline $\mathrm{BT} 1 / 10$ & $41^{\circ} 09.9^{\prime} \mathrm{N}, 2^{\circ} 22.7^{\prime} \mathrm{E}$ & $669-671$ & $18: 20$ & 552 & $\mathrm{D}$ & 93 \\
\hline BT1/11 & $41^{\circ} 10.6^{\prime} \mathrm{N}, 2^{\circ} 24.3^{\prime} \mathrm{E}$ & $649-660$ & $19: 32$ & 536 & $\mathrm{~N}$ & 82 \\
\hline \multicolumn{7}{|l|}{23 March } \\
\hline BT1/12 & $41^{\circ} 01.2^{\prime} \mathrm{N}, 2^{\circ} 16.9^{\prime} \mathrm{E}$ & $1224-1216$ & $01: 28$ & 676 & $\mathrm{~N}$ & 39 \\
\hline BT1/13 & $41^{\circ} 00.5^{\prime} \mathrm{N}, 2^{\circ} 17.0^{\prime} \mathrm{E}$ & $1256-1254$ & $03: 20$ & 602 & $\mathrm{~N}$ & 30 \\
\hline BT1/15 & $41^{\circ} 00.5^{\prime} \mathrm{N}, 2^{\circ} 17.1^{\prime} \mathrm{E}$ & $1211-1214$ & $16: 51$ & 742 & $\mathrm{D}$ & 64 \\
\hline BT1/16 & $41^{\circ} 09.3^{\prime} \mathrm{N}, 2^{\circ} 22.2^{\prime} \mathrm{E}$ & $658-661$ & $19: 12$ & 588 & $\mathrm{~N}$ & 56 \\
\hline
\end{tabular}


slope (northwestern Mediterranean; between $40^{\circ} 12^{\prime}-$ $41^{\circ} 09^{\prime} \mathrm{N}$ and $1^{\circ} 34^{\prime}-2^{\circ} 35^{\prime} \mathrm{E}$ ), and a total of 14 sled samples were obtained. Sampling started at 09:59 h on 21 March 1994 and ended at 19:12 h on 23 March 1994 (Table 1). The Macer-GIROQ sled has 3 superimposed nets (mesh size: $500 \mu \mathrm{m} ; 40 \times 80 \mathrm{~cm}$ rectangular aperture) equipped with an opening-closing mechanical system activated by contact with the sea floor (see Cartes et al. 1994 for a detailed description of the gear). Standard 2030R flowmeters (General Oceanics Inc.) were positioned in the central aperture of the sled mouth, allowing the calculation of water filtered and surface area covered during each haul (Cartes \& Sorbe 1995). The volume of water filtered varied between 388 and $1084 \mathrm{~m}^{3}$ (sampling duration between $\sim 7$ and $17 \mathrm{~min})$. Two bathymetric levels on the slope were sampled simultaneously: 638 to $671 \mathrm{~m}$ and 1192 to $1256 \mathrm{~m}$ soundings. We present results combining samples from both zones.

Simultaneous to the suprabenthic sled samples 3 plankton net hauls were also made in the water column 13 to $55 \mathrm{~m}$ above bottom (mab) at soundings between 644 and $680 \mathrm{~m}$ (Table 1) to detect possible upward migrations by the suprabenthos. The plankton net $\left(1 \mathrm{~m}^{2}\right.$ mouth opening; $500 \mu \mathrm{m}$ mesh size) was equipped with a mechanical opening/closing system (General Oceanics Inc.). The net was also equipped with a pressure SCANMAR sensor to measure the distance from the bottom. Two storms and associated

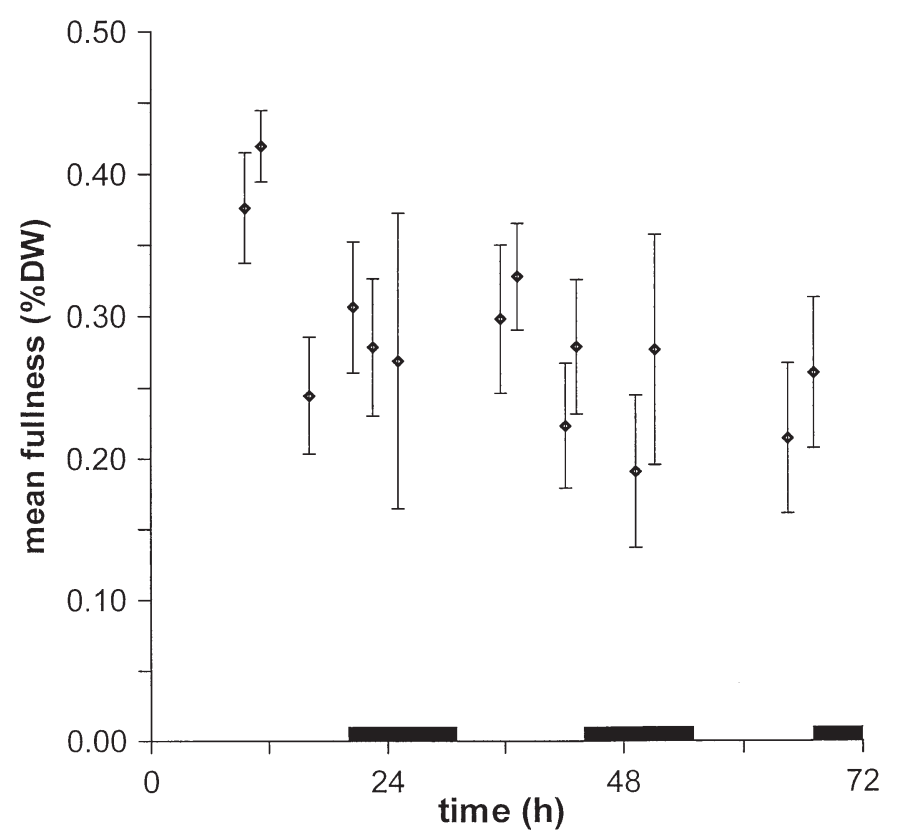

Fig. 1. Boreomysis arctica. Mean stomach fullness $\pm 95 \%$ CI $\left(\mathrm{mm}^{3} \mathrm{mg}^{-1}\right.$ dry wt, DW) during day/night cycle on Cruise BT1 (March 1994). Hauls (= data points in graph) are in the same order as in Table 1 intense deep currents (resulting in the non-functioning of the sled) caused some time gaps in our sampling schedule between BT1/7 and BT1/8 ( 10 h gap) and between BT1/13 and BT1/15 ( 13.5 h gap).

Samples were fixed in buffered formalin (5\%) immediately on collection. Boreomysis arctica, the dominant deep-bathyal mysid in the study area $(68.7 \%$ of total abundance) and the suprabenthic species in terms of biomass (see Cartes \& Sorbe 1995) was the selected target species for studying changes in abundance and stomach fullness. A total of 869 B. arctica individuals were measured (Table 1) with an ocular micrometer, using a stereomicroscope at $\times 10$. The cephalothorax length $(\mathrm{CL}$, in lateral view including the rostrum) was measured on undamaged specimens. Density (individuals $1000 \mathrm{~m}^{-3}$ ) was also calculated for each sample.

The volumetric percentage of stomach fullness $(f)$ was estimated visually under a stereomicroscope, for each individual ( $f=100 \%$, totally full; $f=0 \%$, totally empty). The fine and transparent tegument of the cephalothorax of Boreomysis arctica allowed relatively accurate measurements. The stomach of $B$. arctica is elliptical in shape, and its volume can be estimated as $V=4 / 3 \pi a b c$, where $a, b$, and $c$ are defined as $1 / 2$ of the length (width, length, height) of each stomach, measured at $\times 40$ under a stereomicroscope. These calculations are only a preliminary step in the application of daily rations models, once the stomach volume, stomach fullness and evacuation rates are known. Final volume results ( $\mathrm{mm}^{3}$ of food in stomachs) were transformed to dry weight (DW, mg) by the relationships DW $=0.223 \times$ volume $-0.089\left(r^{2}=0.909 ; n=21\right)$. Specimens were dissected, and DW was obtained after drying gut contents in the oven at $60^{\circ} \mathrm{C}$ for $48 \mathrm{~h}$. Because of the low DW of individual stomach contents, we required data for both single and pooled (3 to 4 ) specimens to establish this regression. Mean $( \pm 95 \% \mathrm{CI})$ percentage fullness was calculated for each sample to detect potential feeding peaks.

Gut-evacuation rates and daily ration. Based on field data, we estimated a constant for gastric evacuation rate $(R)$ based on the $R_{\max }$ estimation procedure (Héroux \& Magnan 1996). From the suprabenthic-sled sampling, we identified 2 significant peaks of stomach fullness (feeding) in Haul BT1/2 on 21 March, and in BT1/9 on 22 March followed by 2 respective significant drops (BT1-4; BT1-10) in stomach fullness (Fig. 1; see below). $R$ was calculated as the difference between the initial and the final stomach contents, following an exponential model (see Héroux \& Magnan 1996, Maynou \& Cartes 1998).

$R$ was also obtained through starvation experiments. During 2 cruises in 1998 (BBC1 cruise: 4 to 5 March; Quimera 2 cruise: 7 to 11 May) a simple experiment to 
estimate $R$ was designed. During the BBC1 cruise, various specimens of Boreomysis arctica (see Table 2) were collected with a suprabenthic MacerGIROQ sled to estimate gut evacuation. The cod-ends of the 3-tiered sled sampler were comprised of 0.91 volume, non-insulated rigid recipients, designed to reduce the damage to captured fauna. Specimens were collected and separated alive from the mid and upper nets of the suprabenthic sled, representing suprabenthos 50 to $140 \mathrm{~cm}$ above the bottom. Individuals in the lower net (between 0 and $50 \mathrm{~cm}$ above bottom) were mixed with some sediment and shell fragments (foraminiferans, pteropods), which probably damage specimens, and this made it impossible to collect live specimens at this level. Living whole specimens, showing mobility and natatory capability, were quickly separated from the original sample and put in plastic dishes, in starved conditions, within an open, filtered-water circulation system connected to sea-surface water. The water column was mixed in March in the study area, and surface temperature was similar $\left(13.7^{\circ} \mathrm{C}_{i} \mathrm{CTD}\right.$ data) to that inhabited by these deepwater species $\left(13.1^{\circ} \mathrm{C}\right)$. In the laboratory, 3 surviving specimens were put in an isothermic chamber at a constant temperature of $13^{\circ} \mathrm{C}$ in the dark. Of the 15 specimens collected on Cruise BBC1, only 4 specimens survived (Table 2) long enough to establish a complete curve of gut evacuation. Live specimens were collected only at depths ranging from 400 to $600 \mathrm{~m}$; no live specimens were ever recovered from the deepest stations below $1200 \mathrm{~m}$ depth. Gastric evacuation rates were therefore estimated from the natural diet. During the Quimera 2 cruise (May 1998) a similar sampling design was attempted. Specimens were caught with a $40 \times 60 \mathrm{~cm}$ plankton net attached to a bottom trawl. The surface water temperature was then around $17.5^{\circ} \mathrm{C}$ (CTD casts); no B. arctica survived long enough to obtain gut-evacuation data.

Periodically specimens were put in petri glass dishes to observe stomach fullness under a stereomicroscope $(\times 10$ to $\times 40)$. Stomach fullness (volume) was visually estimated on a fullness percentage scale $(100 \%=$ full, $0 \%=$ empty) until stomachs had been fully evacuated (ca $2 \mathrm{~h}$ before the starved individuals died).

Once values for $R$ had been obtained, by either of the 2 methods outlined above, $D R$ were calculated by applying 3 widely used models for the computation of $D R$ in fishes: the models of Eggers $(1977,1979)$ and Elliott \& Persson (1978), previously applied to deepwater decapod crustaceans in the same study area (Maynou \& Cartes 1997, 1998). These models (see also
Eggers 1977,1979, Elliott \& Persson 1978, Bromley 1994, Héroux \& Magnan 1996) are:

Model 1: Eggers (1977):

$$
C_{(24 \mathrm{E})}=F_{24} \times R \times 24
$$

where $C$ is the daily ration, and $F_{24}$ is the mean stomach fullness index over $24 \mathrm{~h}$, in \% DW. This model assumes that the weight of the stomach contents does not change between the beginning and the end of the study period.

Model 2: Eggers (1979): when the last assumption cannot be met, Eggers proposed the corrected model:

$$
C_{(24 \mathrm{EC})}=C_{(24 \mathrm{E})}+\left(F_{t=24}-F_{t=0}\right)
$$

where $F_{t=24}$ and $F_{t=0}$ are values of the stomach fullness index at the end and at the beginning of the sampling period.

Model 3: Elliott \& Persson (1978): The food consumed during the time interval $t_{i}$ is:

$$
C_{t_{i}}=\frac{\left(F_{t_{i}}-F_{t_{0}} \mathrm{e}^{-R t_{i}}\right) R t_{i}}{1-\mathrm{e}^{-R t_{i}}}
$$

and the daily ration is the sum of Eq. (3) over the $K$ time intervals considered:

$$
C_{(24 \mathrm{E} \& \mathrm{P})}=\sum_{i=1}^{K} C_{t_{i}}
$$

The assumptions of the Elliott \& Persson model are that food evacuation is exponential and that the rate of food consumption within each sampling interval is constant. Clearly, this model seems a priori the most adequate model to apply to the feeding peaks in the Boreomysis arctica feeding cycle.

The variance of each food consumption estimate $\left(C_{(24 \mathrm{E})}, C_{(24 \mathrm{EC})}\right.$ and $\left.C_{(24 \mathrm{E \& P})}\right)$ was computed following the randomization approach described in Maynou \& Cartes (1997). The variance is expressed as $1.96 \times$ standard error in order to give an approximate $95 \%$ confidence interval around the mean. 


\section{RESULTS}

Significant peaks in percentage stomach fullness of Boreomysis arctica were detected throughout the $\sim 72 \mathrm{~h}$ continuous day/night cycle (Fig. 1). Significant maximum values were detected during BT1/2 (11:23 $h_{\text {; }}$ 21 March), and BT1/9 (13:29 h; 22 March). For BT1/2 fullness were significantly higher than that for BT1/4 to BT1/6 (between 16:09 and 22:53 $\mathrm{h}$; post-hoc Scheffé test; 1-way ANOVA, p < 0.05), BT1/10 to BT1/12 (between 18:20 and 01:28 $h_{;} 22$ and 23 March), and BT1/15-BT1/16 (between 16:51 and 19:12 h; 23 March) (Fig. 1). Fullness on BT1/1 was also significantly higher than on Haul BT1/4. Maximum fullness during BT1/9 was also significantly higher than during BT1/10 (18:20 h), and BT1/15 (16:51 h on 23 March). Note also the significant differences between the 2 maxima (BT1/2 and BT1/9) recorded on 2 consecutive days. In summary, feeding peaks were detected over 2 consecutive days during the morning (between 09:59 and 11:58 h), while during the evening and night (between 16:09 and 01:28 h) fullness decreased significantly over 3 consecutive days.

Mean density $( \pm 95 \% \mathrm{CI}$ ) of Boreomysis arctica at 0.1 to $1.5 \mathrm{~m}$ was higher in daytime $(113.5 \pm 32.5$ ind. $\left.1000 \mathrm{~m}^{-3}\right)$ than in nighttime $\left(75.4 \pm 21.5\right.$ ind. $\left.1000 \mathrm{~m}^{-3}\right)$ samples, although day and night values did not differ significantly (Mann-Whitney $U$-test) (Fig. 2). Densities during the first two $24 \mathrm{~h}$ periods followed similar patterns, increasing during the daytime period, and falling during nighttime. The values obtained at 0.1 to $1.5 \mathrm{~m}$ of the water column were, however, significantly higher than the density of $B$. arctica at 14 to $55 \mathrm{~m}$ above the bottom (collected using the $1 \mathrm{~m}^{2}$ plankton net over similar depths $3.3 \pm 2.9$ ind. $1000 \mathrm{~m}^{-3}$; only 9 specimens collected).

For Boreomysis arctica, $\mathrm{R}_{\Pi}$ oscillated between 0.077 and $0.114 \mathrm{~h}^{-1}$ for the 2 successive feeding peaks on 21 and 22 March. $R_{\max }$ obtained from field data was thus $0.114 \mathrm{~h}^{-1}$ (Fig. 3) for this species. This value was closer to the values obtained in starvation experiments, which were $0.141 \mathrm{~h}^{-1}$ for pooled (3) individuals of between 3.6 and $5.9 \mathrm{~mm}$ CL (Fig. 3), and below $0.345 \mathrm{~h}^{-1}$ for a single individual of $5.6 \mathrm{~mm} \mathrm{CL}$. For our $D R$ calculations we adopted the value of $0.114 \mathrm{~h}^{-1}$, as this was obtained from field data and was very close to the $R$ value for the pooled experimental individuals. We disregarded the extreme $R$ values obtained from the field and from the single starved specimen. For comparison during the same $\mathrm{BBC} 1$ cruise, a value of $R=0.153$ was re-

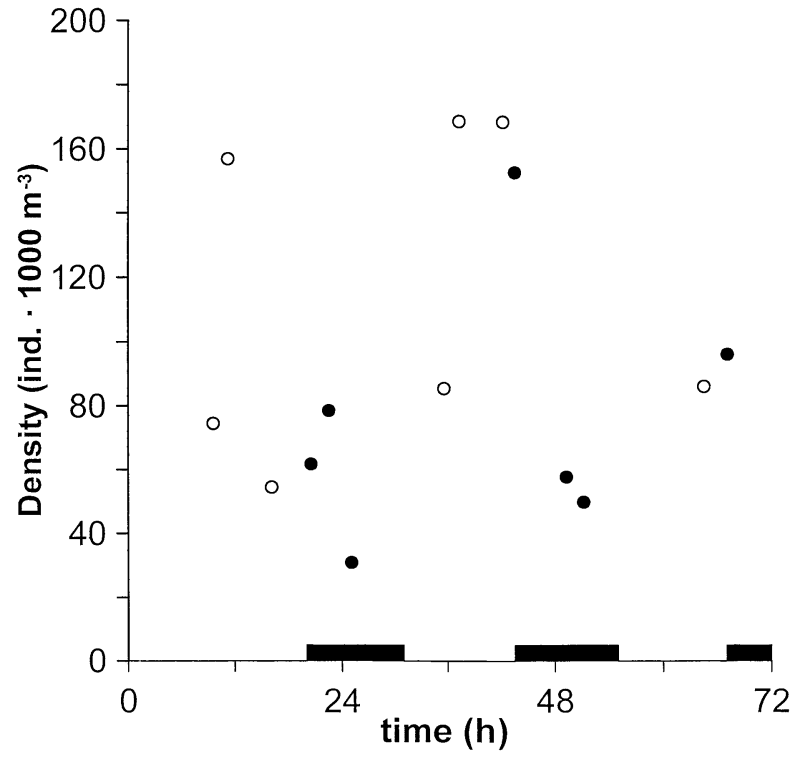

Fig. 2. Boreomysis arctica. Density during continuous BT1 day (o)/night $(\bullet)$ cycle on Cruise BT1

corded for a single adult (8.9 $\mathrm{mm} \mathrm{CL}$ ) specimen of the euphausiid Meganyctiphanes norvegica.

$D R$ was estimated for Boreomysis arctica using different methods (see Table 3). Intermediate $R$ values were adopted for these calculations. With an $R$ of $0.114 \mathrm{~h}^{-1}, D R$ oscillated between 13:51 and 17:10 mg $\mathrm{DW} / \mathrm{mg}$ DW. With an $R$ of $0.141 \mathrm{~h}^{-1}, D R$ varied between 20.64 and $20.50 \%$ DW, applying the Eggers (1977) and (1979) models, and $15.05 \%$ DW applying the Elliott \& Persson (1978) model. The Elliott \& Persson model seems the most appropriate in our case because of the feeding peaks detected in the field sampling. We calculated $D R$ both for each of the 3 consec-

Table 3. Boreomysis arctica. Daily ration, $D R$, for each day and for composite day (3 consecutive days combined) (the 3 d cycle $\pm 95 \% \mathrm{CI}$ ) during Cruise BT1. See Eqs. (1 to 4 ) for details of models

\begin{tabular}{|lrrrrr|}
\hline Model & Day 1 & Day 2 & Day 3 & $\begin{array}{c}\text { Composite 95\% CI } \\
\text { day }\end{array}$ \\
\hline$R=0.114$ & & & & & \\
Eggers (1977) & 20.54 & 16.96 & 14.18 & 17.10 & 0.94 \\
Eggers (1979) & 18.31 & 22.18 & 15.73 & 17.07 & 0.37 \\
Elliott \& Persson (1978) & 7.83 & 14.00 & 13.49 & 13.51 & 0.29 \\
& & & & & \\
$R=0.141$ & & & & & \\
Eggers (1977) & 25.43 & 21.00 & 17.56 & 20.64 & 0.45 \\
Eggers (1979) & 23.19 & 26.22 & 19.11 & 20.50 & 0.45 \\
Elliott \& Persson (1978) & 10.21 & 18.46 & 16.72 & 15.05 & 0.33 \\
\hline
\end{tabular}




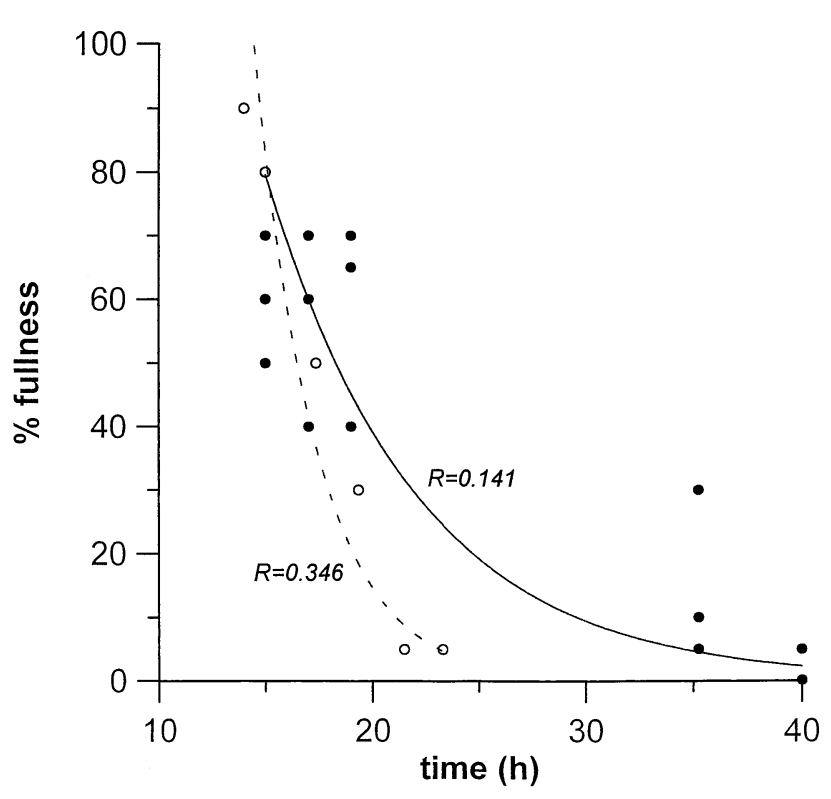

Fig. 3. Boreomysis arctica. Gut-evacuation rates $(R)$ for 3 individuals (data pooled) (O, BBC1/3), and for a single specimen (•, BBC1/5) collected on Cruise BBC1 in March 1998 (see Table 2 for more details)

utive days and for a notional (composite) day. No significant differences in results were obtained with the 2 different approaches (Table 3).

Assuming that $D R$ obtained as \% WW, \% DW or $\%$ bC (where bC = body carbon) are comparable, then $D R$ for Boreomysis arctica usually falls within the $D R$ range reported for mesozooplankton of similar mean size (Fig. 4), and is higher than that reported for large benthopelagic decapods.

\section{DISCUSSION}

Our estimates of $R$ for the deep-sea Boreomysis arctica ranged between 0.114 and $0.345 \mathrm{~h}^{-1}$ (foregut residence time $(1 / R)$ between 2.89 and $8.77 \mathrm{~h})$. From laboratory experiments on freshwater mysids, it has been reported that gut residence time (GRT) depends on temperature, feeding activity and relative stomach fullness (Murtaugh 1984, Chipps 1998). It is also generally accepted that metabolic rates, including $R$, are lower for deep-sea than for shallow-water species in a variety of taxa (Childress 1975, Schwarz \& Colwell 1975, Smith \& Hinga 1983, Koslow 1996). Accordingly, the lowest GRT obtained here for B. arctica $(2.89 \mathrm{~h})$ is close to the value estimated for the freshwater mysid Mysis relicta $\left(2.34 \mathrm{~h}\right.$ at $\left.13^{\circ} \mathrm{C}\right)$ using the equation GRT $=10.367 T^{-0.580}$ (Chipps 1998). The $R$ value of 0.345 , obtained for a single specimen, seems therefore extremely high for our deep-sea species. In contrast, $R=0.141 \mathrm{~h}^{-1}$ seems a more realistic value because it was obtained from a pool of starved mysids and is closer to the $R_{\max }$ obtained from field sampling ( $R=$ $0.114 \mathrm{~h}^{-1}$ ). The effect of other factors, such as the influence of feeding activity and relative stomach fullness, on $R$ could not be tested with our approach. Although it has been documented that these factors can influence the value of $R$ obtained in freshwater mysids (Murtaugh 1984), they are also probably subject to methodological problems such as starvation period (Persson 1979, Chipps 1998) and the artificial diets used. These factors were not regarded as significant in determining the $R$ of fishes and decapod crustaceans in other studies (Elliott \& Persson 1978, Maynou \& Cartes 1998). In contrast, it is widely recognized that temperature is the main factor affecting $R$, in both laboratory and field conditions (Chipps 1998 and references therein). In the deep western Mediterranean, the temperature is constant year round $\left(13^{\circ} \mathrm{C}\right)$ at bathyal depths below $200 \mathrm{~m}$, thus excluding any temperature-related variability in $R$ estimates. In summary, estimating $R$ in 2 independent ways (starvation and field data), seems a suitable approach for the application of $D R$ models.

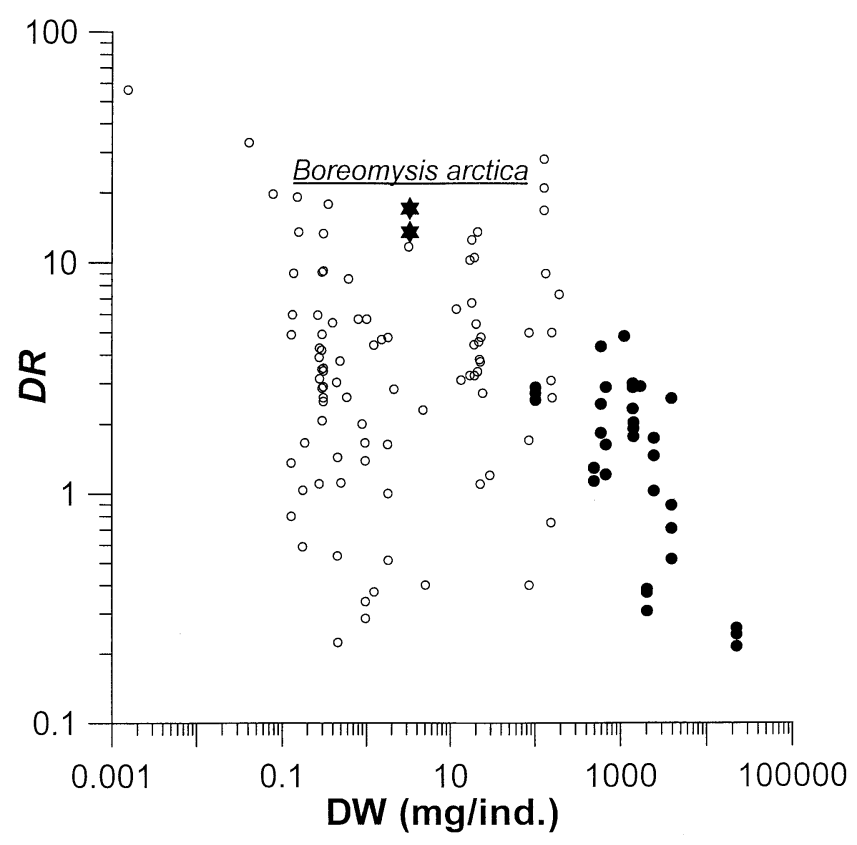

Fig. 4. Boreomysis arctica. Daily ration, $D R$ compared to that for other benthic, benthopelagic and pelagic crustacean species: (•) deep-sea decapod data from Maynou \& Cartes (1997, 1998); (O) pelagic euphausiid, hyperiid and copepod data obtained from the list of references cited. $D R$ was expressed as in the original data sets as wet wt, dry wt, or \% body $\mathrm{C}$. Mean weight was transformed to mg dry wt ind. ${ }^{-1}$ 
The results obtained for Boreomysis arctica, for both $R$ and $D R$, seem, in general, consistent with other results obtained for mesozooplankton species and for some deep-water megafaunal crustaceans (Fig. 4). The value of $R$ for $B$. arctica (between 0.114 and $0.345 \mathrm{~h}^{-1}$ ) is close to or within the range obtained for the hyperiid Themisto gaudichaudi and for adult Euphausia superba (between 0.133 and $0.424 \mathrm{~h}^{-1}$ : Pakhomov et al. 1997a) and clearly below or in the lower part of the range of $R$ obtained for some furcilia and juvenile stages of euphausiids (between 0.819 and $1.07 \mathrm{~h}^{-1}$ : Pakhomov et al. 1997b), and for copepods and the ostracods Conchoecia spp. (between 0.23 and 1.96; Perissinotto 1992, and data summarized by Pakhomov et al. 1997b). Our deep-water mysid showed $R$ within ranges similar to those of deep-water megabenthic decapod crustaceans (between 0.179 and 0.312: Maynou \& Cartes 1998) dwelling at the same environmental temperature $\left(13.1^{\circ} \mathrm{C}\right)$, thus supporting the proposal that temperature influences GRT (Elliott \& Persson 1978, Chipps 1988, Héroux \& Magnan 1996). The low minimum $R$ estimated for $B$. arctica, compared to predatory decapods $\left(R=0.114 \mathrm{~h}^{-1}\right)$ may be explained by the lower gut-evacuation rates of grazing species ingesting material of plant origin. This is the case of $B$. arctica, for which a substantial consumption of phytodetritus (25 to $60 \%$ of stomach volume) has been documented (Cartes \& Sorbe 1998).

The daily ration obtained using Elliott \& Persson's method (1978) with $R=0.114 \mathrm{~h}^{-1}$ was $13.51 \% \mathrm{DW}$. It is often difficult to establish general comparisons of $D R$ between different taxa feeding at diverse trophic levels, because different authors express $D R$ in various forms, from \% WW to \% of body $\mathrm{C}$, and conversion factors are often difficult to apply correctly. Despite this difficulty and bearing in mind these assumptions, our $D R$ value for Boreomysis arctica was higher than the range of $D R$ reported for deep-sea decapod crustaceans in the same area (between 0.260 and $4.820 \%$ DW), particularly in regards to the value obtained for crabs and lobsters (between 0.260 and 0.384: Maynou \& Cartes 1998). DR in B. arctica was also higher than that estimated for highly mobile (epipelagic) fish (1.30 to $3.92 \%$ WW: Tudela \& Palomera 1995, Koslow 1996), and particularly for non-migratory and benthopelagic deep-water fish (0.05 to 4.0: Clarke 1978, Macpherson 1985, Gorelova 1986, Koslow 1996, expressed in \% WW or \% DW).

In contrast, $D R$ for Boreomysis arctica fell within the $D R$ range often reported for zooplankton (euphausiids, hyperiids, calanoids; Fig. 3). It was higher than values reported for Euphausia superba (0.4 to $5 \%$ body carbon: Pakhomov et al. 1997a), and for the hyperiid Themisto gaudichaudi $(6.3 \%$ in vivo: Pakhomov \& Perissinotto 1996); and within values reported for
Euphausia spp. (2.6 to 21.1\%: Ponomareva \& Kuznetsova 1995 and references therein) and for meso- and macroplankton taxa, including calanoids and euphausiids (0.37 to 56.06: calculated from ingestion rate data given in Pakhomov et al. 1997b).

Boreomysis arctica is probably a filter-feeder, consuming phytodetritus, although it also feeds on crustacean carcasses (Cartes \& Sorbe 1998). B. arctica had a relatively high swimming capacity in the water layer 0 to $1.4 \mathrm{~m}$ above the bottom, while its density in midwaters is very low (Macquart-Moulin 1993, present study). Phytodetritus may therefore be consumed at the sediment-water interface, where deposition of phytodetritus flocs to bathyal and abyssal depths exceeding $5000 \mathrm{~m}$ has been documented with indirect methods (bottom photographs: Hecker 1990) and with direct observation of core samples (Smith et al. 1996). Assuming a pattern similar to that described for migrator/non-migrator fishes (see Koslow 1996), i.e. higher $D R$ for more active migratory fish than for benthic/ bathypelagic non-migratory species, the $D R$ of $B$. arctica, a deep-bathyal non-migrator species would be expected to be lower than that of migratory zooplankton. However, our $D R$ results place this species within similar food-consumption ranges as observed in epipelagic/midwater euphausiids (Fig. 4). Although this suggests a possible overestimation of $D R$ for $B$. arctica in our study, another plausible explanation could lie in the high grazing rates (comparable to those of neritic zooplankton) reported for in situ mixed (meso-)zooplankton assemblages in the BBL of the North Atlantic Ocean at $2175 \mathrm{~m}$ depth (Wishner \& Meise-Munns 1984). Our results support the notion that the deep-sea $\mathrm{BBL}$ maybe a region of elevated grazing rates and activity, mainly due to a near-bottom increase in particulate organic matter (Wishner \& Gowing 1987, 1992).

Our $D R$ results are also consistent with recently published production data for Boreomysis arctica in the same area (Cartes \& Sorbe 1999). Adopting the same mean annual biomass (B) value used to calculate production for Boreomysis arctica $\left(\mathrm{B}=1.695 \mathrm{mg} \mathrm{DW} \mathrm{m}^{-2}\right.$ $\mathrm{yr}^{-1}$ ), the annual food consumption (C) of this species would be between 83.6 and $105.8 \mathrm{mg} \mathrm{mg} \mathrm{DW} \mathrm{m}^{-2} \mathrm{yr}^{-1}$. Secondary production estimates range between 5.22 and $9.00 \mathrm{mg} \mathrm{m}^{-2} \mathrm{yr}^{-1}$ depending on the method used (see Cartes \& Sorbe 1999). The P/C ratio would, therefore, be situated between 4.9 and $10.7 \%$. P/B ratios obtained by Cartes \& Sorbe for B. arctica are also consistent with other published data for marine mysids (from coastal to deep-shelf species: Cartes \& Sorbe 1999). The estimation of ecological efficiency (EE) in $B$. arctica was not an objective of the present study, since $\mathrm{C}$ and $\mathrm{P}$ were obtained from studies carried out at different time scales. However, the EE here deduced, was 
slightly below or within to the commonly accepted EE transfers (10 to $23 \%$ ), and constitutes an additional argument to validate our $D R$ results for a (preliminary) energy-balance approach.

The annual food consumption (C) of Boreomysis arctica (83.6 to $105.8 \mathrm{mg} \mathrm{DW} \mathrm{m}^{-2}$ ) is equivalent to 15.89 to $20.09 \mathrm{mg} \mathrm{C} \mathrm{m}^{-2} \mathrm{yr}^{-1}$, considering the C/DW conversion of $19 \%$ of $\mathrm{C}$ in total mass flux (cf. Miquel et al. 1994) and also the low selective diet of this mysid based on a variety of planktonic food sources. Our extrapolations to an annual scale probably overestimate annual trophic impact by $B$. arctica because its higher food consumption in March, a period in which small juveniles dominate the population, and a higher stomach fullness has been reported (Cartes \& Sorbe 1998). Experimental and field studies have both demonstrated how changes in food supply determine, for instance, the ration of copepods (Poulet 1974, Deason 1980, Wishner \& Meise-Munns 1984). Despite this and comparing with data on vertical flux, food consumption by $B$. arctica on an annual scale would be equivalent to $1.1-1.4 \%$ of the total average mass-flux arriving at $1000 \mathrm{~m}$ depth $\left(22 \mathrm{mg} \mathrm{m}^{-2} \mathrm{~d}^{-1}\right)$ in an open-ocean area of the neighbouring Ligurian Sea (Miquel et al. 1994). As $\sim 39.7 \%$ of the annual stomach volume of $B$. arctica is composed of phytodetritus (Cartes \& Sorbe 1998), it can roughly be assumed that at most $8 \mathrm{mg} \mathrm{C}$ $\mathrm{m}^{-2} \mathrm{yr}^{-1}$ are consumed as phytodetritus from the total $\mathrm{C}$ consumed by $B$. arctica. This represents $0.01 \%$ of the $77 \mathrm{~g} \mathrm{C} \mathrm{m}^{-2} \mathrm{yr}^{-1}$ (Jacques 1988, Minas et al. 1988) surface primary production reported as the mean primary production in the northwestern Mediterranean.

Because of the low proportion of vertical fluxes that reaches at bottom depths (5 to $7 \%$ of primary production), it seems more realistic to compare the trophic impact of a benthopelagic species with the organic matter available in the sediment/water interface than with that in water-column fluxes data. Sedimented organic matter data are, however, very scarce and are subject to strong temporal pulses in continental margin ecosystems (Buscail et al. 1990). In view of this, and of the mean annual organic carbon consumption $(0.6 \mathrm{~g} \mathrm{C}$ $\mathrm{m}^{-2}$ : in situ oxygen consumption measurements) of the sediment community of the neighbouring Lacaze Canyon, Boreomyis arctica would hardly consume $3.4 \%$ of the $\mathrm{C}$ consumed by sediment community. In the northwestern Mediterranean, the organic carbon content of sediments is 1.5 times higher inside canyons (subject to strong $\mathrm{C}$ exportation by advective fluxes from the shelf) than on interfluve slopes (Buscail et al. 1990). Therefore, for the open-slope area where our mysids were collected, a value of $3.4 \%$ would probably underestimate the trophic impact of $B$. arctica.

The trophic impact of Boreomysis arctica seems low in view of its dominance in the bathyal assemblage, being lower than the impact often reported for mesopelagic species. Euphausiids (i.e. Euphausia superba), hyperiids or copepods, consume between 0.3 and $70 \%$ of the total production at their respective trophic levels (Perissinotto 1992, Froneman et al. 1996, 1997, Pakhomov \& Perissinoto 1996, Pakhomov et al. 1997b), even though only autotrophic material (not the total food consumed) was considered in many such studies on plankton species. A comparatively lower trophic impact of a benthic species would be expected considering the higher diversification of benthic macrofauna, particularly in the deep-sea environment, compared to plankton communities. Rather than being due to diet specialization, the low specific trophic impact by BBL species such as $B$. arctica is consistent with the notion of resource-partitioning postulated to support high diversity in the benthos, particularly in deep-sea communities (Sanders 1968, Gage \& Tyler 1991). Compartments other than the suprabenthos may directly exploit sediment matter; these may include infauna (decapods, polychaetes, echinoderms, etc.) or even some megafauna species. Among the latter, and particularly in dominant deep-water species below 1200 m (e.g., Nematocarcinus exilis, Munida tenuimana), increased detritivory has been shown, compared to mid-bathyal species (Cartes 1998). Bacterial biomass is also important in deep-sea benthic Mediterranean communities (Delille et al. 1990, Danovaro et al. 1993). Although the trophic role of nanobiota is still poorly known in the deep Mediterranean (Danovaro et al. 1993), bacteria probably metabolize a fairly important part of the sedimented matter, whereas deposit-feeding macrofauna (or even megafauna) may consume nanobiota-enriched detritus. Whatever the case, it is difficult to obtain a complete trophic balance for benthic communities due to the in basic trophic-web structure compared to the more linear (i.e., chain-like) trophic structure of plankton communities.

Acknowledgements. The authors thank the co-participants in the project AMB93/0283 and the crew of the RV 'García del Cid' for their helpful assistance during sampling at sea. The project were funded by the CICYT (Comisión Interministerial de Ciencia y Tecnología-Ministry of Research and Science), while the LEA (Laboratorios Europeos Asociados) financed the BBC1 cruise.

\section{LITERATURE CITED}

Atkinson A, Ward P, Williams R, Poulet SA (1992) Feeding rates and diel vertical migration of copepods near South Georgia: comparison of shelf and oceanic sites. Mar Biol 114:49-56

Bromley PJ (1994) The role of gastric evacuation experiments in quantifying the feeding rates of predatory fish. Rev Fish Biol Fish 4:36-66 
Bulman CM, Koslow JA (1992) Diet and food consumption of a deep-sea fish, orange roughy Hoplostethus atlanticus (Pisces: Trachichthydae), off southeastern Australia. Mar Ecol Prog Ser 82:115-129

Buscail R, Pocklington R, Daumas R, Guidi L (1990) Fluxes and budget of organic matter in the benthic boundary layer over the northwestern Mediterranean. Cont Shelf Res 10:1089-1122

Carrasson M, Matallanas J, Casadevall M (1998) Feeding strategies of deep-water morids on the Western Mediterranean. Deep-Sea Res 44:1685-1700

Cartes JE (1998) Feeding strategies and partition of food resources in deep-water decapod crustaceans in relation to depth (between 400-2300 m). J Mar Biol Assoc UK 78: 509-524

Cartes JE, Maynou F (1998) Food consumption by bathyal decapod crustacean assemblages in the western Mediterranean: an approach to predatory impact and to a food consumption-food supply balance in a deep-water food web. Mar Ecol Prog Ser 171:233-246

Cartes JE, Sorbe JC (1995) Deep-water mysids of the Catalan Sea: species composition, bathymetric and near-bottom distribution. J Mar Biol Assoc UK 75:187-197

Cartes JE, Sorbe JC (1998) Aspects of population structure and feeding ecology of the deep-water mysid Boreomysis arctica, a dominant species in western Mediterranean slope assemblages. J Plankton Res 20(12):2401-2411

Cartes JE, Sorbe JC (1999) Estimating secondary production in bathyal suprabenthic peracarid crustaceans from the Catalan Sea slope (western Mediterranean; 391-1255 m). J Exp Mar Biol Ecol 239:195-210

Cartes JE, Sorbe JC, Sardà F (1994) Spatial distribution and swimming activity of deep-sea decapods and euphausiids near the bottom in the Northwestern Mediterranean. J Exp Mar Biol Ecol 179:131-144

Childress JJ (1975) The respiratory rates of midwater crustaceans as a function of depth of occurrence and relation to the oxygen minimum layer off Southern California. Comp Biochem Physiol 50A:787-799

Chipps SR (1998) Temperature-depending consumption and gut-residence time in the opossum shrimp Mysis relicta. J Plankton Res 20:2401-2411

Clarke TA (1978) Diel feeding patterns of 16 species of mesopleagic fishes from Hawaiian waters. Fish Bull 76:495-513

Danovaro R, Fabiano M, Della Croce N (1993) Labile organic matter and microbial biomasses in deep-sea sediments (Eastern Mediterranean Sea). Deep-Sea Res 40:953-965

Deason EE (1980) Grazing of Acartia hudsonica (A. clausi) on Skeletonema costatum in Narragansett Bay (USA): influence of food concentration and temperature. Mar Biol 60: 101-113

Delille D, Guidi LD, Cahet G (1990) Temporal variation of benthic bacterial microflora on the North Western Mediterranean continental shelf and slope. PSZN I: Mar Ecol 11:105-115

Durbin EG, Durbin AG, Langton RW, Bowman, RE (1983) Stomach contents of silver hake, Merluccius bilinearis, and Atlantic code, Gadus morhua, and estimation of their daily rations. Fish Bull 81:437-454

Eggers DM (1977) Factors in interpreting data obtained by diel sampling of fish stomachs. J Fish Res Board Can 34: 290-294

Eggers DM (1979) Comments on some recent methods for estimating food consumption by fish. J Fish Res Board Can 36:1018-1019

Elliott JM, Persson L (1978) The estimation of daily rates of food consumption for fish. J Anim Ecol 47:977-991
Froneman PW, Pakhomov EA, Perissinotto R, McQuaid CD (1996) Role of microplankton in the diet and daily ration of Antarctic zooplankton species during austral summer. Mar Ecol Prog Ser 143:15-23

Froneman PW, Pakhomov EA, Perissinotto R, Laubscher RK, McQuaid CD (1997) Dynamics of the plankton communities of the Lazarev Sea (Southern Ocean) during seasonal ice melt. Mar Ecol Prog Ser 149:201-214

Gage JD, Tyler PA (1991) Deep sea biology: a natural history of organisms at the deep-sea floor. Cambridge University Press, Cambridge

Gorelova TA (1986) Assessment of the daily ration of mesoand bathypelagic fishes of the family Bathylagidae. J Ichthyol 25:155-160

Hecker B (1990) Photographic evidence for the rapid flux of particles to the sea floor and their transport down the continental slope. Deep-Sea Res 37:1773-1782

Héroux D, Magnan P (1996) In situ determination of food daily ration in fish: review and field evaluation. Environ Biol Fish 46:61-74

Jacques G (1988) Flux de carbone en milieu pélagique de Méditerranée occidentale lors de la floraison printanière. Oceanol Acta (Spec Issue) 9:143-148

Jumars PA, Gallagher ED (1982) Deep-sea community structure: three plays on the benthic proscenium. In: Ernst WG, Morin JG (eds) The environment of the deep sea. Prentice Hall, Englewood Cliffs, NJ, p 217-255

Koslow JA (1996) Energetic and life-history patterns of deepsea benthic, benthopelagic and seamount-associated fish. J Fish Biol 49(Suppl A):54-74

Macpherson E (1985) Daily ration and feeding periodicity of some fishes off the coast of Namibia. Mar Ecol Prog Ser 26: 253-260

Macquart-Moulin C (1993) Répartition verticale, migrations et stratifications superficielles des mysidacés et amphipodes pélagiques sur les marges méditerranées et atlantiques françaises. J Plankton Res 15:1149-1170

Maynou F, Cartes JE (1997) Estimation of daily ration on field in the deep-sea shrimp Aristeus antennatus. Mar Ecol Prog Ser 153:191-196

Maynou F, Cartes JE (1998) Daily ration estimates and comparative study of food consumption in deep-water decapod crustaceans of the NW Mediterranean. Mar Ecol Prog Ser 171:221-231

Minas HJ, Minas M, Coste B, Gostan J, Nival P, Bonin MC (1988) Production de base et de recyclage: une revue de la problématique en Méditerranee nord-occidentale. Oceanol Acta (Spec Issue) 9:155-162

Miquel JC, Fowler SW, La Rosa J, Buat-Menard P (1994) Dynamics of the downward flux of particles and carbon in the open northwestern Mediterranean Sea. Deep-Sea Res 41:243-261

Murtaugh PA (1984) Variable gut residence time: problems in inferring feeding rate from stomach fullness of a mysid crustacean. Can J Fish Aquat Sci 42:1287-1293

Pakhomov EA, Perissinotto R (1996) Trophodynamics of the hyperiid amphipod Themisto gaudichaudi in the South Georgia region during late austral summer. Mar Ecol Prog Ser 134:91-100

Pakhomov EA, Perissinotto R, Froneman PW, Miller DGM (1997a) Energetics and feeding dynamics of Euphausia superba in the South Georgia region during the summer of 1994. J Plankton Res 19:399-423

Pakhomov EA, Verheye HM, Atkinson A, Laubscher RK, Taunton-Clark J (1997b) Structure and grazing impact of the mesozooplankton community during late summer 1994 near South Georgia, Antarctica. Polar Biol 18:180-192 
Perissinotto R (1992) Mesozooplankton size selectivity and grazing impact on the phytoplankton community of the Prince Edward Archipelago (Southern Ocean). Mar Ecol Prog Ser 79:243-258

Perissinotto R, Pakhomov EA, Mcquaid CD, Froneman PW (1997) In situ grazing rates and daily ration of Antarctic krill Euphausia superba feeding on phytoplankton at the Antarctic Polar Front and the Marginal Ice Zone. Mar Ecol Prog Ser 160:77-91

Persson L (1979) The effects of temperature and different food organisms on the rate of gastric evacuation in perch (Perca fluviatilis). Freshw Biol 9:99-104.

Peterson W, Painting S, Barlow R (1990) Feeding rates of Calanoides carinatus: a comparison of five methods including evaluation of the gut fluorescence method. Mar Ecol Prog Ser 63:85-92

Ponomareva LA, Kuznetsova IA (1995) Euphausiids of the Namibian upwelling and trophic characteristics of a common species, Euphausia hanseni. Russ J Mar Biol 21:8-11

Poulet SA (1974) Seasonal grazing of Pseudocalanus minutus on particles. Mar Biol 25:109-123

Sanders HL (1968) Marine benthic diversity: a comparative study. Am Nat 102:243-282

Schwarz JR, Colwell RR (1975) Heterotrophic activity of deepsea sediment bacteria. Appl Environ Microbiol 30:639-649

Editorial responsibility: Otto Kinne (Editor),

Oldendorf/Luhe, Germany
Smith CR, Hoover DJ, Doan SE, Pope RH, Demaster DJ, Dobbs FC, Altabet MA (1996) Phytodetritus at the abyssal seafloor across $10^{\circ}$ of latitude in the central equatorial Pacific. Deep-Sea Res 43:1309-1338

Smith KL Jr, Hinga KR (1983) Sediment community respiration in the deep sea. In: Rowe GT (ed) Deep-sea biology. John Wiley \& Sons, London, p 331-370

Tudela S, Palomera I (1995) Diel feeding intensity and daily ration in the anchovy Engraulis encrasicholus in the northwest Mediterranean Sea during the spawning period. Mar Ecol Prog Ser 129:55-61

Ward P, Atkinson A, Murray AWA, Wood AG, Williams R, Poulet S (1995) The summer zooplankton community at South Georgia: biomass, vertical migration and grazing. Polar Biol 15:195-208

Wishner KF, Gowing MM (1987) In situ filtering and ingestion rates of deep-sea benthic boundary layer zooplankton in the Santa Catalina Basin. Mar Biol 94:357-366

Wishner KF, Gowing MM (1992) The role of deep-sea zooplankton in carbon cycles. In: Rowe GT, Pariente V (eds) Deep-sea food chains and the global carbon cycle. Kluwer Academic Publishers, Dordrecht, p 29-44

Wishner KF, Meise-Munns CJ (1984) In situ grazing rates of deep-sea benthic boundary-layer zooplankton. Mar Biol 84:65-74

Submitted: April 13, 2000; Accepted: June 27, 2000

Proofs received from author(s): February 5, 2001 